\title{
KAJIAN EMPIRIS DAN ETNOFARMAKOLOGI TUMBUHAN HUTAN BERKHASIAT OBAT ASAL DESA TUMBANG RUNGAN KELURAHAN PAHANDUT KOTA PALANGKARAYA KALIMANTAN TENGAH
}

\author{
Empirical and Ethnopharmacological Study of Efficacious Medicinal Forest Plants from \\ Tumbang Rungan Village, Pahandut Regency, Palangkaraya City, Central Kalimantan
}

\section{Nurul Qamariah \\ Rezqi Handayani* \\ Susi Novaryatiin}

Universitas Muhammadiyah Palangkaraya, Palangka Raya,

Central Kalimantan, Indonesia

*email:

rezqi.handayani@gmail.com

Kata Kunci:

THBO

Obat Tradisional

Desa Tumbang Rungan

\section{Keywords:}

Medicinal Plants

Traditional Medicines

Tumbang Rungan Village

Accepted

September 2018

Published

December 2018

\begin{abstract}
Abstrak
Desa Tumbang Rungan merupakan salah satu desa yang terdapat di Kecamatan Pahandut Kota Palangka Raya Kalimantan Tengah. Desa ini merupakan salah satu lokasi yang memiliki potensi yang besar akan Tumbuhan Hutan Berkhasiat Obat (THBO). Banyak obat tradisional yang di pasarkan di wilayah Kalimantan Tengah berbahan baku THBO asal dari desa Tumbang Rungan. THBO asal Desa Tumbang Rungan dipercaya masyarakat dapat mengobati berbagai macam penyakit diantaranya yaitu mengobati radang amandel, batuk, meredak asma, penambah stamina pada lakilaki, antidiabetes, diuretik, dan mengobati luka. Tetapi hal ini masih bersifat empiris dan belum ada dat ilmiahnya. Oleh karen itu penelitian ini dilakukan untuk menginventarisasi THBO asal Desa Tumbang Rungan dan melakukan studi pustaka untuk mencari data ilimiah baik senyawa aktif yang terkandung maupun efek farmokologis yang dibandingkan dengan empirisnya. Hasil penelitian didapatkan sebelas THBO asal Desa Tumbang Rungan yang berkhasiat sebagai obat tradisional. Sembilan tumbuhan diantaranya telah didapatkan data ilmiahnya mengenai senyawa aktif dan efek farmakologisnya. Hasil penelitian ini nantinya dapat menajdi acuan untuk penelitian selanjutnya demi mengembangkan potensi lokal Kalimantan Tengah dalam pengobatan tradisional.
\end{abstract}

\begin{abstract}
Tumbang Rungan Village is one of the villages located in Pahandut District, Palangka Raya City, Central Kalimantan. This village is one of the locations that have great potential for medicinal herbs (THBO). Many traditional medicines are marketed in the Central Kalimantan region made from THBO from the village of Tumbang Rungan. THBO from Tumbang Rungan Village is believed by the community to be able to treat various diseases including treating tonsillitis, coughing, asthma explosions, stamina enhancer in men, antidiabetic, diuretic, and healing wounds. But this is still empirical, and there is no scientific data. Therefore, this research was conducted to inventory THBO from Tumbang Rungan Village and do a literature study to look for experimental data on both active compounds and pharmacological effects compared to practical ones. The results of the survey obtained eleven THBO from Tumbang Rungan Village which is efficient as traditional medicines. Nine plants including scientific data have been collected regarding active compounds and their pharmacological effects. The results of this study can later become a reference for further research to develop the local potential of Central Kalimantan in traditional medicine.
\end{abstract}

\section{PENDAHULUAN}

Kekayaan alam hutan tropis Indonesia menyimpan berbagai tumbuhan yang berkhasiat sebagai obat dan dihuni oleh berbagai suku dengan pengetahuan pengobatan tradisional yang berbeda. Indonesia memiliki lebih dari 1.000 jenis tumbuhan yang dapat digunakan sebagai obat dan sekitar 300 jenis yang sudah dimanfaatkan untuk pengobatan tradisional (Handayani \& Rusmita, 2017). Hutan merupakan salah satu sumber daya alam yang memberi manfaat bagi manusia, baik ekologis maupun ekonomis. Sumber daya hutan dibagi dalam dua bagian yaitu hasil hutan berupa kayu dan hasil hutan non kayu. Hasil hutan non kayu yang sering dimanfaatkan oleh masyarakat sekitar hutan salah satunya adalah tumbuhan obat (Takoy et al., 20l3).

Sumber daya hutan dapat dibagi dalam dua bagian yaitu berupa hasil hutan kayu beserta turunannya (timber product) dan hasil hutan bukan kayu (non-timber product). 
Salah satu hasil hutan bukan kayu yang sering dimanfaatkan masyarakat di sekitar hutan adalah tumbuhan berkhasiat obat (Setiawan \& Krisnawati, 2014). Diperkirakan 30.000 jenis tumbuhan ditemukan di dalam hutan tropika indonesia, I.260 jenis di antaranya berkhasiat sebagai obat. Meskipun demikian, baru sekitar 180 jenis yang telah digunakan untuk keperluan industri obat herbal dan jamu (Nugroho et al., 2015).

Nenek moyang kita dengan pengetahuan yang dimiliki dan peralatan yang sederhana menggunakan berbagai jenis tumbuhan untuk pengobatan penyakit. Penyakit ringan maupun berat diobati dengan menggunakan ramuan dari jenis tumbuh-tumbuhan tertentu yang terdapat di sekitar pekarangan rumah dan di hutan. (Wibisino \& Azham, 2017). Penggunaan tumbuhan obat sudah dilakukan oleh manusia sejak dikenalnya proses meramu dan masih berlangsung hingga kini. Penggunaan tumbuhan obat ini kerap digunakan oleh orang banyak karena relatif memiliki efek samping yang kecil dan lebih murah bila dibandingkan dengan obatobatan sintetis (Meliki et al., 20l3). Tumbuhan obat adalah semua spesies tumbuhan yang menghasilkan satu atau lebih komponen aktif yang digunakan untuk perawatan kesehatan dan pengobatan atau seluruh spesies tumbuhan yang diketahui atau dipercaya mempunyai khasiat obat (Nurrani et al., 20l4). Tumbuhan berkhasiat obat adalah jenis tumbuhan yang pada bagianbagian tertentu baik akar, batang, kulit, daun maupun hasil ekskresinya dipercaya dapat menyembuhkan atau mengurangi rasa sakit (Zulfiani et al., 2015). Tumbuhan obat adalah seluruh spesies tumbuhan obat yang diketahui dan dipercaya mempunyai khasiat obat, yang dikelompokkan menjadi 3 kelompok tumbuhan obat, yaitu Tumbuhan obat tradisional, yaitu spesies tumbuhan yang diketahui atau dipercaya memiliki khasiat obat dan telah digunakan sebagai bahan obat tradisional, Tumbuhan obat modern, yaitu spesies tumbuhan yang secara ilmiah telah dibuktikan mengadung senyawa atau bahan bioaktif yang berkhasiat obat dan penggunaannya dapat dipertanggungjawabkan secara medis, dan Tumbuhan obat potensial, yaitu spesies tumbuhan yang diduga mengandung senyawa atau bahan bioaktif yang berkhasiat obat, tetapi belum dibuktikan secara ilmiah atau penggunannya sebagai bahan obat tradisional (Sari et al., 20l4).

Dayak adalah salah satu kelompok besar penduduk asal atau sering disebut "penduduk asli" pulau Kalimantan. Mereka tersebar di wilayah administratif Propinsi Kalimantan Barat, Kalimantan Tengah, Kalimantan Selatan dan Kalimantan Timur. Suku Dayak dibagi ke dalam tujuh kelompok yaitu Ngaju, Apu Kayan, Iban, Klematan atau Darat, Murut, Punan, Ahe dan Danum (Darmadi, 2016). Suku Dayak merupakan salah satu suku asli Indonesia yang dapat dijumpai di seluruh pelosok kalimantan, bahkan sampai ke Serawak, Sabah dan Brunei Darussalam. Sub-sub suku Dayak mempunyai budaya dan adat istiadat yang berbeda satu sama lain. Suku Dayak hidup di sekitar kawasan hutan yang di dalamnya terdapat tumbuh-tumbuhan yang berkhasiat sebagai obat (Takoy et al., 2013).

Kalimantan Tengah merupakan salah satu provinsi dengan mayoritas masyarakatnya hingga saat ini merupakan suku Dayak. Tumbuhan obat bukanlah hal asing bagi masyarakat suku Dayak di Kalimantan Tengah. Tumbuhan obat hingga saat ini menajdi salah satu pilihan bagi masyarakat suku Dayak Kalimantan Tengah dalam terapi pengobatan (Pitoyo \& Triwahyudi, 2017). Salah satu daerah di Kalimantan Tengah yang memilki potensi besar berasalnya tumbuhan obat adalah Desa Tumbang Rungan Kelurahan Pahandut Kota Palangkaraya Kalimantan Tengah. Pengenalan terhadap berbagai jenis tumbuhan obat adalah hal yang dapat dilakukan sebelum kita melakukan penyebarluasan pemanfaatan terhadap tumbuhan obat itu sendiri. Selama ini pengetahuan tentang obat tradisional hanya diperoleh melalui informasi masyarakat tetapi masih belum dieksplorasi (Gunadi et al., 20I7). 
Oleh karena itu, perlu adanya identifikasi jenis-jenis tumbuhan obat yang sering dimanfaatkan oleh masyarakat Desa Tumbang Rungan Kelurahan Pahandut Kota Palangkaraya Kalimantan Tengah. Selain berfungsi sebagai sarana untuk mendekatkan masyarakat kepada pemanfaatan tumbuhan obat, juga berfungsi sebagai sarana untuk mengikuti sertakan masyarakat di dalam upaya pelestarian sumber daya alam khususnya sumber daya alam bukan kayu. Untuk mengetahui jumlah dan jenis-jenis tumbuhan obat yang sering digunakan oleh masyarakat, maka dilakukannya penelitian tentang studi. Pendugaan tumbuhan obat diharapkan tidak hanya menjadi sebuah dokumentasi pengetahuan tradisional dalam pemanfaatan tumbuhan untuk generasi-generasi berikutnya (Sari et al., 20I4). Tetapi juga sebagai salah satu modal dalam pengembangan dan kelestarian sumber daya alam di Desa Tumbang Rungan.

\section{METODOLOGI}

Alat dan bahan yang digunakan dalam penelitian ini adalah GPS, kamera digital, alat perekam, spritus, kantong plastik, gunting tanaman, kertas merang, kertas label, kertas mounting, benang, sprayer, panduan wawancara yang sudah dipersiapkan terlebih dahulu dan buku Identifikasi. Pengumpulan data primer merupakan pengumpulan informasi mengenai lokasi hutan atau daerah yang memiliki potensi besar akan THBO. Pengumpulan informasi dilakukan dengan melakukan wawancara kepada para penjual tumbuhan obat tradisional untuk mendapatkan informasi mengenai tumbuhan apa saja yang berkhasiat sebagai obat dan tempat atau lokasi tumbuh tumbuhan tersebut (Irwanta et al., 20I5). Salah satu lokasi yang mempunyai potensi besar akan tumbuhan obat dan telah menjadi penyuplai bahan baku obat tradisional adalah Desa Tumbang Rungan Kelurahan Pahandut Kota Palangkaraya Kalimantan Tengah.

Observasi langsung dilaksanakan untuk melakukan inventarisasi THBO dan pengambilan sampel tumbuhan untuk di lakukan penelitian determinasi. Observasi langsung dilaksanakan dengan mendatangi hutan atau daerah tempat tumbuh THBO di Desa Tumbang Rungan Kelurahan Pahandut Kota Palangkaraya Kalimantan Tengah. Daerah tempat tumbuh ini diketahui dari wawancara yang dilakukan oleh tim kepada masyarakat setempat atau pengumpul bahan baku obat tradisional.

THBO yang telah diambil dari lokasi tempat tumbuhnya selanjutnya dibawa ke Laboratorium Farmakognosi Fakultas IImu Kesehatan untuk dibuat menajdi herbarium kering. Herbarium kering ini selanjutnya dikirim ke Laboratorium Biologi Lembaga Ilmu Pengetahuan Indonesia untuk dilakukan determinasi. Tujuan determinasi adalah untuk mengetahui jenis atau spesies THBO yang akan diperlukan pada saat studi pustaka efek farmakologis yang dihasilkan (Umar et al., 2016).

Berdasarkan hasil identifikasi oleh laboratorium Pusat Litbang Konservasi dan Rehabilitasi Bogor, tim peneliti kemudian melakukan studi literatur untuk mendapatkan data ilmiah mengenai kandungan metabolit sekunder dan efek farmakologi THBO asal Kalimantan Tengah yang telah terdata. Hasil studi literatur kemudian dicocokkan dengan hasil studi empiris pada data primer yang telah didapat. Analisis data dilakukan sejak penelitian dilakukan, oleh karena itu data yang diperoleh dari lapangan segera disalin dalam bentuk tulisan dan kemudian dianalisis. Penarikan kesimpulan dilakukan dengan metode triangulasi data yaitu peneliti menggunakan berbagai sumber data yang dapat digunakan selama riset atau penelitian dilakukan. Pada penelitian ini triangulasi yang dilakukan adalah menyimpulkan dari hasil wawancara masyarakat mengenai penggunaan THBO Desa Tumbang Rungan Kelurahan Pahandut Kota Palangka Raya sebagai obat tradisional, hasil determinasi tumbuhan obat dan studi literatur yang dilakukan oleh tim peneliti. Dari hasil triangulasi data tersebutlah akan didapatkan kebenaran 
secara ilmiah mengenai khasiat THBO asal Desa

Tumbang Rungan Kelurahan Pahandut Kota

Palangkaraya sebagai obat tradisional.

\section{HASIL DAN PEMBAHASAN}

Hasil inventarisasi yang dilakukan di Desa Tumbang Rungan Kelurahan Pahandut Kota Palangkaraya Kalimantan Tengah didapatkan II THBO yang dipercaya masyarakat setempat sebagai obat tradisional. Hasil inventarisasi dapat dilihat pada Tabel I dibawah ini:

Tabel I. Hasil Inventarisasi THBO di Desa Tumbang Rungan

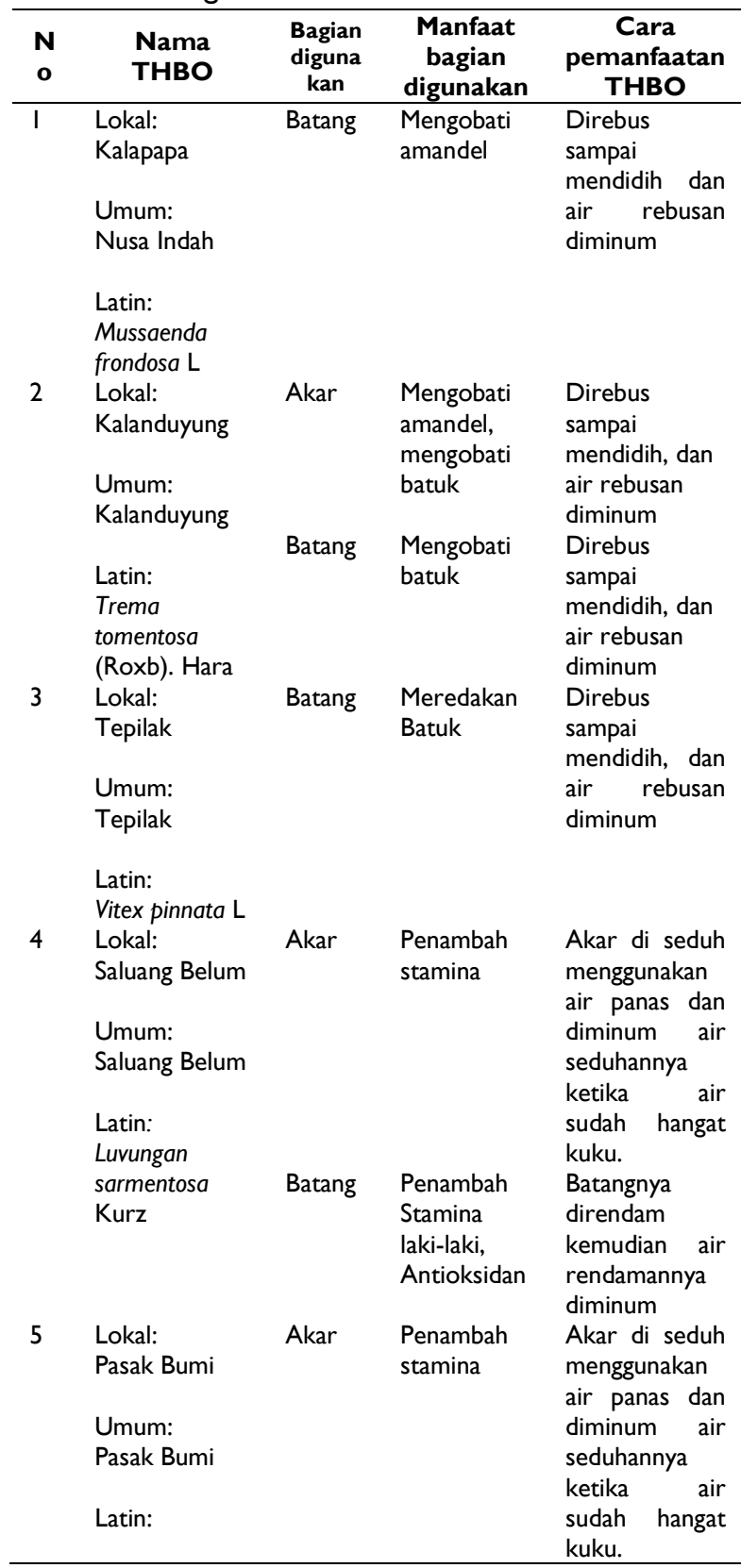

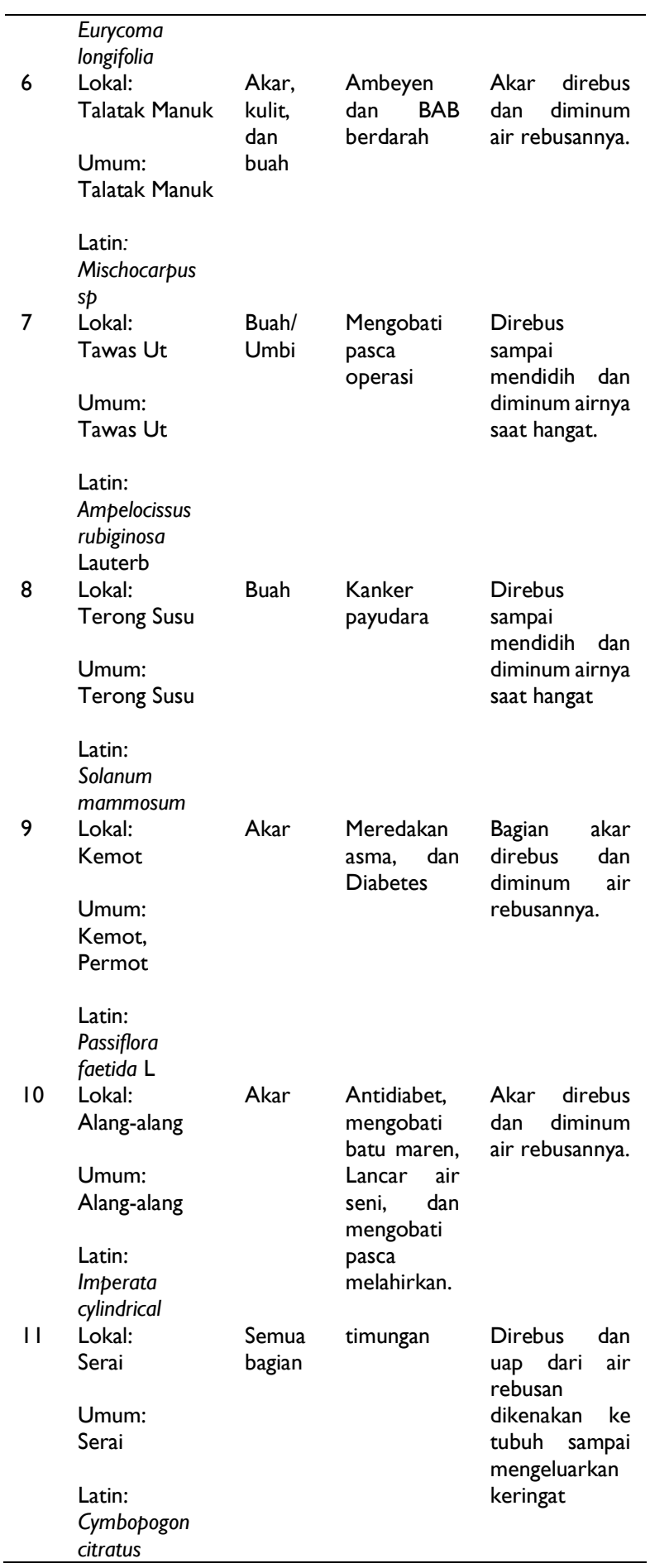

Pada tabel diatas terlihat bahwa semua bagian dari tumbuhan dapat dimanfaatkan sebagai obat tradisional. Hasil inventarisasi di Desa Tumbang Rungan Kelurahan Pahandut Kota Palangkaraya Kalimantan Tengah didapatkan bagian tumbuhan yang paling banyak digunakan adalah bagian akar dan batang. Penggunaan kedua bagian tumbuhan tersebut oleh masyarakat adalah merebus kedua bagian tersebut hingga mendidih 
kemudian meminum air rebusannya. Air rebusan tersebutlah yang dipercaya oleh masyarakat setempat mengobati berbagai macam penyakit diantaranya mengobati radang amandel, batuk, meredak asma, penambah stamina pada laki-laki, antidiabetes, diuretik, dan mengobati luka. Khasiat tersebut merupakan khasiat empiris yang belum terbukti secara ilmiah. dan studi pustaka telah dilakukan untuk II THBO Desa Tumbang Rungan Kelurahan Pahandut Kota Palangka Raya Kalimantan Tengah. Hasil studi yang didapat sebagai berikut Batang Kalapapa (Mussaenda frondosa L) digunakan masyarakat sebagai mengobati radang amandel. Menurut catatan ilmiah, tumbuhan ini dikatakan mengandung efek antioksidan. Alkaloid dan flavonoid dikatakan mengandung zat yang selain baik untuk antioksidan, juga baik sebagai nutrisi buat tubuh. Di tanaman ini, selain mengandungi zat-zat tersebut, ada pula karbohidrat, steroid, tanin, polifenol, dan terpenoid (Siju et al., 20l0). Di India, akar tanaman ini dipakai untuk mengobati luka pada lidah. Sedangkan, daun kelopaknya dipakai sebagai diuretik/peluruh kencing. Selain itu pula, bisa dikatakan tanaman ini bermanfaat sebagai antibakteri (Vidyalakshmi et al., 2008). Tetapi untuk penelitian efek farmakologis pada radang amandel belum ditemukan. Batang Kalapapa digunakan oleh masyarakat untuk mengobati amandel. Batang Kalapapa termasuk ke dalam suku Rubiaceae, sebagian besar Rubiaceae telah teruji dan menunjukkan aktivitas yang signifikan terhadap beberapa bakteri patogen (Choudhury et al., 20I2). Penelitian lain menunjukkan bahwa Batang Kalapapa memiliki spektrum yang luas, memiliki aktivitas antibakteri terhadap 6 dari 7 mikroorganisme yang diujikan (Jayasinghe et al., 2002).

Batang Saluang Belum (Luvungan sarmentosa Kurz) digunakan masyarkat sebgaai obat penambah stamina pada laki-laki atau dalam bidang farmasi sebagai Afrodisiaka dan dipercaya masyarakat sebagai antioksidan. Batang Salaung Belum diduga mempunyai aktifiitas afrodisiaka walaupun masih perlu dibuktikan secara penelitian Farmakologis. Hal ini dikarenakan dari hasil penelitian diketahui bahwa batang Saluang Belum memiliki kandungan metabolit sekunder yaitu saponin dan tannin (Handayani et al., 2018; Qamariah et al., 2018). Saponin meningkatkan libido melalui mekanisme kerja langsung pada sistem saraf pusat dan jaringan gonad. Aksi sentral dari saponin yaitu meningkatkan kadar LH dan FSH, meningkatkan produksi androgen melalui jalur langsung maupun tidak langsung. Saponin (steroid glikosida) berperan dalam biosintesis DHEA (dehydroepiandrosteron) sehingga meningkatkan kadar testosteron dalam tubuh dan memacu libido. Melalui mekanisme ini, saponin mampu meningkatkan kadar hormon testosteron. Kadar testosteron dilaporkan memiliki hubungan dengan LH dan FSH, seperti peningkatan kadar gonadotropin bersamaan dengan peningkatan kadar testosteron (Pratab \& Rajendar, 2012). Dari hasil kualitatif senyawa kimia yang terkandung di dalam kedua simplisia tersebut, khasiat awat muda yang dipercaya masyarakat dpaat dibuktikan secara ilmiah. Hal ini dikarenakan kedua simplisia tersebut mengandung senyawa kimia yang memeliki aktifitas sebagai antioksidan. Antioksidan senyawa kimia yang berhubungan erat dengan pencegahan penuaan atau senyawa kimia yang mampu membuat kulit menjadi awet muda. Penuaan merupakan proses dimana terjadi kemunduran atau derenegrasi yang menyebabkan berbagai organ tubuh kehilangan fungsi dan kemampuannya, termasuk menyebabkan munculnya keriput dan garis halus di wajah atau bagian tubuh lain. Radikal bebas sendiri bisa menyerang, mempercepat proses penuaan dan menyebabkan penuaan dini baik dari dalam maupun luar tubuh, karena sumber radikal bebas ada dua jenis yakni radikal bebas yang berasal dari dalam diri seperti proses metabolisme tubuh dan yang berasal dari luar seperti polusi, asap rokok dan sinar UV (Pratama \& Suhartono, 2018). Antioksidan merupakan senyawa yang berfungsi untuk menangkal radikal bebas. Antioksidan akan menetralisir radikal bebas untuk mencegah kerusakan sel dalam tubuh termasuk kulit agar kulit terlihat lebih sehat, indah dan selalu tampak 
awet muda. Antioksidan didefinisikan sebagai senyawa yang mampu menunda, memperlambat atau menghambat reaksi oksidasi makanan atau obat. Antioksidan merupakan zat yang mampu melindungi sel melawan kerusakan yang ditimbulkan oleh radikal bebas (Reactive Oxygen Species), seperti singlet oksigen, superoksid, radikal peroksid dan radikal hidroksil (Sinaga, 2016).

Senyawa kimia yang memiliki aktivitas sebagai antioksidan dan terdapat dalam batang Saluang Belum tersebut adalah tanin. Tanin merupakan senyawa aktif metabolit sekunder yang diketahui mempunyai beberapa khasiat yaitu sebagai astringen, anti diare, anti bakteri dan antioksidan. Tanin merupakan komponen zat organik yang sangat kompleks, terdiri dari senyawa fenolik yang sukar dipisahkan dan sukar mengkristal, mengendapkan protein dari larutannya dan bersenyawa dengan protein tersebut (Karina et al., 2016). Tanin dibagi menjadi dua kelompok yaitu tanin terhidrolisis dan tanin terkondensasi. Tanin memiliki peranan biologis yang kompleks mulai dari pengendap protein hingga pengkhelat logam. Tanin juga dapat berfungsi sebagai antioksidan biologis (Hagerman, 2002).

Akar pasak bumi secara empiris digunakan sebagai penambah stamina pada lelaki. Tumbuhan pasak bumi mengandung zat pahit eurikomalakton dan amarolida, quassinoid, alkaloid, saponin, dan stigmasterol (Panjaitan et al., 2009; Itjin \& Kuswibawati, 2004). Pasak bumi berkhasiat sebagai stomakik dan antipiretik, disentri amuba, dan obat demam. Sariawan, badan lemah, darah kotor, menyembuhkan sakit pinggang karena kelelahan, meningkatkan daya vitalitas tubuh sebagai obat kuat laki-laki. Kata libido secara harfiah artinya nafsu kelamin. Secara luas didefinisikan sebagai dorongan naluri kreatif untuk mendapatkan kepuasan, terutama kepuasan seksual (Itjin \& Kuswibawati, 2004). Pada umumnya pengujian terhadap peningkatan libido dapat dilakukan dengan 2 cara, yaitu melihat efek androgenik (cara hormonal) dan mengamati tingkah laku seksual tikus (Itjin \& Kuswibawati, 2004). Hasil penelitian menunjukkan bahwa lama pemberian infusa akar pasak bumi meningkatkan libido tikus putih jantan, yang ditunjukkan adanya peningkatan jumlah pendekatan (introduksi) dan penunggangan (climbing) tikus putih jantan terhadap tikus putih betina.

Akar Kemot (Passiflora foetida L.) digunakan oleh masyarakat untuk meredakan asma dan diabetes. Tumbuhan ini diketahui mengandung flavonoid, harmalin, harmin, harmol, saponin, saponaretin, saponarin, dan sitosterol (Susilowati, 2017). Akar Kemot berpotensi untuk meredakan asma dan sebagai antidiabetes, dengan cara pengolahan akar tersebut direbus lalu diminum air rebusannya (Noorcahyati, 20I2). Salah satu tumbuhan yang digunakan sebagai obat luka yakni tawas ut (Ampelocissus rubiginosa Lauterb.), yang merupakan tumbuhan perdu dari famili Vitaceae dan berasal dari Kalimantan Tengah. Secara empiris umbi tawas ut dipercaya memiliki banyak khasiat, diantaranya sebagai obat luka luar maupun luka dalam setelah melahirkan dan operasi. Pada penelitian sebelumnya telah terbukti bahwa infusa umbi tawas ut berefek sebagai, antibakteri terhadap Escherichia coli dan Staphylococcus aureus serta sebagai antiplasmodium (Arnida et al., 2015). Hasil skrining fitokimia menunjukkan pada umbi tawas ut terdapat alkaloid, flavonoid, tanin, dan saponin, sehingga diduga kandungan tersebut mempunyai aktivitas sebagai obat luka. Hasil penelitian menunjukkan kelompok uji 2,5\% memiliki aktivitas penyembuhan luka dengan rerata persentase penutupan panjang luka $99 \% \pm 0,16$, rerata tensile strength $3,854 \mathrm{I} \mathrm{g} / \mathrm{mm}^{2}$, disertai terjadinya reepitelisasi, neokapilerisasi, dan peningkatan kepadatan kolagen pada pengamatan histopatologi. Berdasarkan penelitian ini dapat disimpulkan gel ekstrak etanol umbi tawas ut memiliki aktivitas penyembuhan luka (Anwar et al., 2018).

Buah Terong Susu (Solanum mammosum) dipercaya masyarakat dapat mengobati kanker payudara. 
Berdasarkan penelitian yang telah dilakukan marga tumbuhan ini yaitu solanum telah dikenal sejak lama sebagai bahan baku utama dalam produksi hormon steroid progesteron adalah diosgenin dan solasodin. Sumber diosgenin yang potensial untuk Indonesia berasal dari umbi tanaman Dioscorea $s p$, terutama $D$. composita, D. Deltiodea, D. Floribunda dan dari rimpang dan biji Costus speciosus (pacing), tetapi jenis-jenis ini di Indonesia kadar diosgeninnya rata-rata rendah (Winarti et al., 20II). Sedangkan sumber solasodin berasal dari beberapa jenis solanum antara lain adalah S. tuberosum (kentang), S. melongena (terong), S. nigrum (leunca), S. mammosum L (terung susu), $S$. jasminoides, $S$. seafothianum, S. auriculatum, S. capsicoides, $S$. capsicastrum, S. Indicum L, dan S. Khasianum. Tetapi sampai saat ini belum ditemukan penelitian farmakologi buah terung susu terhadap kanker payudara.

Sereh (Cymbopogon citratus) digunakan masyarakat sebagai salah satu bahan yang digunakan untk timungan. Sampai saat ini belum ditemukan secara ilmiah mengenai khasiat sereh dalam timungan. Tetapi hasil penelitian menunjukkan bahwa sereh memeliki senyawa aktif yaitu senyawa aktif citral dan geranial yang memiliki sifat anti jamur dan anti mikroba serta memunculkan bau lemon yang khas. Terdapat 7 senyawa dengan persentase lebih dari I \% yaitu $\beta$-myrcene, 3-undecyne, neral, citral, geranial, nerol, geranyl acetate, dan juniper camphor. Tanaman berkhasiat obat ini banyak sekali mengandung minyak atsiri, dan sumber penting seperti vitamin $A, B_{1}$ (tiamin), $\quad B_{2} \quad$ (riboflavin), $\quad B_{3} \quad$ (niasin), $\quad B_{5} \quad$ (asam pantotenat), $B_{6}$ (pyridoxine), asam folat, flavonoid, senyawa fenolik dan vitamin C (Hadijah et al, 20l6).

Dari hasil studi pustaka yang dilakukan, terdapat 3 THBO yang belum ditemukan literaturnya yaitu Kalanduyung dan Tepilak yang secara empiris digunakan sebagai obat batuk, serta Talatak manuk yang digunakan sebagai obat disenstri dan ambeyen. Hasil ini dapat menjadi acuan penelitian selanjutnya untuk melakukan identifikasi senyawa kimia yang terkandung dan efek farmakologisnya ketiga tumbuhan tersebut yang dibandingkan dengan khasiat empirisnya.

\section{KESIMPULAN}

Berdasarkan hasil inventarisasi yang dilakukan didapatkan hasil terdapat II THBO asal Desa Tumbang Rungan Kelurahan Pahandut Kota Palangkaraya Kalimantan Tengah yang berkhasiat sebagai obat. dan bagian tumbuhan yang digunakan sebagai obat tradisional yaitu daun, batang, buah, umbi, dan seluruh bagian Tumbuhan.

\section{UCAPAN TERIMA KASIH}

Terimakasih yang sebesar-besarnya disampaikan kepada Direktorat Riset dan Pengabdian Kepada Masyarakat, Direktorat Jenderal Penguatan Riset dan Pengembangan, Kementrian Riset, Teknologi Pendidikan Tinggi Republik Indonesia atas dana yang diberikan untuk kegiatan penelitian ini.

\section{REFERENSI}

Anwar, K., Widodo, D.F., Nurlely, Triyasmono, L., Sudarsono, \& Nugroho, A.E. 2018. Aktivitas Gel Ekstrak Etanol Umbi Akar Tawas Ut (Ampelocissus rubiginosa L.) Terhadap Penyembuhan Luka Insisi Pada Tikus Wistar. Majalah Obat Tradisional. 23(I):30-39.

Arnida, Wahyono, Mustofa, \& Asmahsusidarti, R. 2015. In Vitro Antiplasmodial Activity of Ethanol Extracts of Borneo Medicinal Plants (Hydrolea spinosa, Ampelocissus rubiginosa, Uraria crinite, Angiopteri sevecta), International Journal of Pharmacy and Pharmaceutical Sciences. 7(5):72-75.

Choudhury, K., Choudhury, M., \& Baruah, M. 20I2. Anti Bacterial Activity of Some Plants Belonging to The Family Rubiaceae. Journal of Pharmacy and Pharmaceutical Sciences. I (3): I I 79- I I 94.

Darmadi, H. 2016. Dayak Asal-Usul dan Penyebarannya di Bumi Borneo (I). Sosial Horizon: Jurnal Pendidikan Sosial. 3(2):322-340. 
Gunadi, D., Oramahi, H.A., \& Tavita, G.E. 2017. Studi Tumbuhan Obat pada Etnis Dayak di Desa Gerantung Kecamatan Monterado Kabupaten Bengkayang. Jurnal Hasil Hutan. 5(2):425-436.

Hadijah, S., Hendra, M., \& Hariani, N. 2016. Etnomotani Obat Tradisional oleh Masyarakat Kutai di Kec. Muara Bengkal Kab. Kutai Timur. Bioprospek. I I (2): I 9-24.

Hagerman, A. E. 2002. The Tannin Handbook. Ohio: Miami University.

Handayani, R., Qamariah, N., \& Mardova, S.A. 20I8. Uji Daya Hambat Ekstrak Etanol Batang Saluang Belum terhadap Bakteri Escherichia coli. Borneo Journal of Pharmacy. I(I): I6- I8.

Handayani, R. \& Rusmita, H. 2017. Uji Daya Hambat Ekstrak Etanol Akar Kelakai (Stenochlaena palustris (Burm. F.) Bedd.) terhadap Bakteri Escherichia coli. Jurnal Sutya Medika (JSM). 2(2):13-26.

Irwanta, E., Hikmat, A., \& Zuhud, E.A.M. 2015. Keanekaragaman Simplisia Nabati dan Produk Obat Tradisional yang Diperdagangkan di Kabupaten Pati, Jawa Tengah. Media Konservasi. 20(3):197-204.

Itjin, D. \& Kuswibawati, L. 2004. Pengaruh infusa akar Pasak Bumi (Eurycoma longifolia Jack.) terhadap libido tikus putih jantan. Majalah Farmasi Indonesia. I5(3): I30-135.

Jayasinghe, L., Jayasooriya, C.P., Bandara, B.M.R., Ekanayake, S.P., Merlini, L., \& Assante, G. 2002. Antimicrobial activity of some Sri Lankan Rubiaceae and Meliaceae. Fitoterapeia, 73(5):424-427.

Karina, Indrayani, Y., \& Sirait, S.M. 20I6. Kadar Tanin Biji Pinang (Areca catechu L) berdasarkan Lama Pemanasan dan Ukuran Serbuk. Jurnal Hutan Lestari. 4(I): I 19-127.

Meliki, Linda, R., \& Lovadi, I. 2013. Etnobotani Tumbuhan Obat oleh Suku Dayak Iban Desa Tanjung Sari Kecamatan Ketungau Tengah Kabupaten Sintang. Protobiont: Jurnal Elektronik Biologi. 2(3): I 29- I 35.

Noorcahyati. 2012. Tumbuhan berkhasiat obat etnis asli Kalimantan. Balikpapan: Balai Penelitian Teknologi Konservasi Sumber Daya Alam.

Nugroho, A.S., Anis, T., \& Ulfah, M. 2015. Analisis keanekaragaman jenis tumbuhan berbuah di hutan lindung Surokonto, Kendal, Jawa
Tengah dan potensinya sebagai Kawasan konservasi burung. Prosiding Seminar Nasional Masyarakat Biodiversitas Indonesia. I(3):472476.

Nurrani, L., Kinho, J., \& Tabba, S. 2014. Kandungan Bahan Aktif dan Toksisitas Tumbuhan Hutan asal Sulawesi Utara yang Berpotensi Sebagai Obat. Jurnal Penelitian Hasil Hutan. 32(2): I 23138.

Panjaitan, R.G.P., Jayuska, A., Harahap, Z., \& Zakiah, Z. 2009. Pemberian Akar Pasak Bumi (Eurycoma longifolia Jack.) pada Induk Laktasi untuk Meningkatkan Bobot Badan Anak Mencit. Makara Sains. I3(2): 195-199.

Pitoyo, A.J. \& Triwahyudi, H. 2017. Dinamika Perkembangan Etnis di Indonesia dalam Konteks Persatuan Negara. Populasi. 25(I):64-8I.

Pratama, M.R.F. \& Suhartono, E. 20I8. Understanding the Interaction Between Glutathione and Acetaminophen: A Docking Study Approach. Dentino: Jurnal Kedokteran Gigi. 3(2):215-219.

Pratap, S.A. \& Rajender, S. 2012. Potent Natural Aphrodisiacs for The Management of Erectile Dysfunction and Male Sexual Disabilities. Frontiers in Bioscience. I(4): I67-180.

Qamariah, N., Handayani, R., \& Friskila, A. 2018. Uji Daya Hambat Ekstrak Etanol Batang Tumbuhan Saluang Belum Terhadap Bakteri Staphylococcus aureus. Jurnal Surya Medika (JSM). 4(I):90-101.

Setiawan, O. \& Krisnawati. 20I4. Pemilihan Jenis Hasil Hutan Bukan Kayu Potensial dalam Rangka Rehabilitasi Hutan Lindung (Studi Kasus Kawasan Hutan Lindung KPHL Rinjani Barat, Nusa Tenggara Barat). Jurnal Ilmu Kehutanan. 8(2):89-99.

Sari, R.Y., Wardeenar, E., \& Muflihati. 20I4. Etnobotani Tumbuhan Obat di Dusun Serambai Kecamatan Kembayan Kabupaten Sanggau Kalimantan Barat. Jurnal Hutan Lestari. 2(3):379-387

Siju, E.N., Rajalakshmi, G.R., Kavitha, V.P., \& Joseph, A. 2010. In vitro antioxidant activity of Mussaenda Frondosa. International Journal of PharmTech Research. 2(2): I 236-I 240.

Sinaga, F.A. 2016. Stress Oksidatif dan Status Antioksidan pada Aktivitas Fisik Maksimal. Jurnal Generasi Kampus. 9(2): I76- 189. 
Susilowati, R.P. 2017. Efektivitas Daun Permot (Passiflora foetida) sebagai Obat Nyamuk dan Pengaruhnya pada Sel Darah Mencit. Jurnal Kedokteran Meditek. 23(62): I - I0.

Takoy, D.M., Linda, R., \& Lovadi, I. 2013. Tumbuhan berkhasiat obat suku Dayak Seberuang di kawasan hutan Desa Ensabang Kecamatan Sepauk Kabupaten Sintang. Protobiont: Jurnal Elektronik Biologi. 2(3): I22-I28.

Umar, A.H., Syahruni, R., Burhan, A., Maryam, F., Amin, A., Marwati, \& Masero, L.R. 2016. Determinasi dan Analisis Finger Print Tanaman Murbei (Morus alba Lour) sebagai Bahan Baku Obat Tradisional dengan Metode Spektroskopi FT-IR dan Kemometrik. Pharmacon. 5(I):78-90.

Vidyalakshmi, K.S., Vasnthi, H.R., \& Rajangkam, G.V. 2008. Ethnobotany, Phytochemistry, and Pharmacology of Mussaenda Species (Rubiaceae). Ethnobotanical Leaflets. 12:469475.

Wibisono, Y. \& Azham, Z. 2017. Inventarisasi Jenis Tumbuhan yang Berkhasiat Sebagai Obat pada Plot Konservasi Tumbuhan Obat di KHDTK Samboja Kecamatan Samboja Kabupaten Kutai Kartanegara. Agrifor: Jurnal IImu Pertanian dan Kehutanan. I6(I): I25-I40.

Winarti, S., Harmayani, E., \& Nurismanto, R. $201 \mathrm{I}$. Karakteristik dan Profil Inulin Beberapa Jenis Uwi (Dioscorea spp.). Agritech. 3I(4):378383.

Zulfiani, Z., Yuniati, E., \& Ramadhanil, R. 2015. Kajian Etnobotani Suku Kaili Tara Di Desa Binangga Kecamatan Parigi Tengah Kabupaten Parigi Moutong Sulawesi Tengah. Biocelebes. $8(1): 29-36$. 